\title{
RESPON PETANI PADI SAWAH TERHADAP PENGGUNAAN PUPUK ORGANIK CAIR DI GAMPONG BLANG CUT KECAMATAN SUKAMAKMUR KABUPATEN ACEH BESAR
}

\author{
Rice Farmers Response To The Use Of Liquid Oganic Fertilizers In Gampong Blang Cut \\ Sukamakmur District, Aceh Besar District
}

\author{
Munzirin ${ }^{1}$, Azhar ${ }^{1}$, Irwan A.Kadir ${ }^{*}$ \\ ${ }^{1}$ Program Studi Agribisnis, Fakultas Pertanian, Universitas Syiah Kuala
}

\begin{abstract}
Abstrak. Penelitian ini bertujuan untuk Mengetahui faktor- faktor yang mempengaruhi respon petani padi terhadap penggunaan pupuk organik cair dan juga untuk mengetahui respon petani padi terhadap penggunaan pupuk organik cair di Gampong Blang Cut Kecamatan Sukamakmur Kabupaten Aceh Besar. Metode penelitian ini adalah asosiatif dilakukan dengan teknik survei menggunakan kuisioner. Penentuan lokasi penelitian dilakukan secara sensus yaitu di Desa Blang Cut. Sampel ditentukan dengan teknik proporsional random sampling sebanyak 20 responden petani yang ada di desa Blang Cut. Jenis dan sumber data meliputi data primer dan sekunder. Metode analisis yang digunakan untuk mengkaji faktor-faktor yang mempengaruhi respon dan respon petani padi dalam penggunaan pupuk organik Cair adalah Skala Likert dengan rumus lebar interval. Hasil penelitian menunjukkan bahwa faktor-faktor yang mempengaruhi respon adalah manfaat yang diharapkan dari penggunaan pupuk dalam kategori sedang, $65 \%$ responden menganggap pupuk Organik Cair sangat membantu dalam memenuhi kebutuhan pupuk, membantu dalam meningkatkan produksi padi, dan membantu atau mempermudah dalam pengolahan lahan; selang waktu antara awal pen0ggunaan dengan memperoleh manfaat pupuk sebagian besar dalam kategori (baik), 100\% responden mengetahui bahwa pupuk Organik Cair lebih lama memberikan dampak terhadap tanaman. Respon petani padi dalam penggunaan pupuk Organik Cair adalah respon kognitif sebagian besar petani responden dalam kategori baik, $75 \%$ responden memahami pupuk Organik cair; respon afektif petani responden sebagian besar dalam kategori baik, 92,5\% responden setuju apabila pupuk Organik Cair menghemat pupuk kimia komersial; respon konatif petani responden sebagian besar dalam kategori sedang, $45 \%$ responden menggunakan pupuk antara sepertiga hingga duapertiga dosis yang dianjurkan.
\end{abstract}

Kata kunci: Respon, pupuk organik cair, penyuluhan pertanian, dan lingkungan sosial.

\begin{abstract}
This study aims to determine the factors that influence the response of farmers to the use of liquid organic fertilizer and the response of farmers to the use of liquid organic fertilizer in Blang Cut Village, Sukamakmur District, Aceh Besar District. This research method is associative method which is done by using questionnaire survey technique. Determination of the location of the study was conducted in a census, namely in the Village of Blang Cut. The sample was determined by proportional random sampling technique as many as 20 farmer respondents in the village of Blang Cut. Types and sources of data include primary and secondary data. The analytical method used to assess the factors that influence the response and response of rice farmers in the use of liquid organic fertilizers is a Likert scale with the formula width interval. The results showed that the factors that influence the response of farmers are the expected benefits from the use of fertilizer in the medium category. There are $65 \%$ of respondents consider Organic Liquid fertilizer to be very helpful in meeting fertilizer needs, helping in increasing rice production, and assisting or facilitating land processing; the time interval between the start of use and the benefits of fertilizer is mostly in the (good) category. There are $100 \%$ of respondents know that Organic Liquid fertilizer has a longer impact on plants. The response of rice farmers in the use of Organic Liquid fertilizer is cognitive response. Most of the respondents are in good category, $75 \%$ of respondents understand liquid Organic fertilizer; affective responses of respondent farmers are mostly in good category. There are $92.5 \%$ of respondents agree that Liquid Organic fertilizer saves commercial chemical fertilizers; the conative response of the respondent farmers is mostly in the medium category, $45 \%$ of respondents use fertilizer between one third to two thirds of the recommended dose.
\end{abstract}

Keywords: Response, liquid organic fertilizer, agricultural extension, and Social environment 


\section{PENDAHULUAN}

Sektor pertanian memiliki peranan strategis dalam pembangunan nasional, baik untuk menunjang pertumbuhan ekonomi maupun pemerataan pembangunan. Peran strategis pertanian terhadap pertumbuhan ekonomi, yaitu sebagai sumber pendapatan lebih dari $70 \%$ penduduk Indonesia, penyedia pangan untuk penduduk Indonesia, kegiatan ekspor produk pertanian menghasilkan devisa negara, penyedia bahan baku industri, dapat meningkatkan lapangan kerja dan usaha, meningkatkan pendapatan daerah, menurunkan angka kemiskanan, dan juga memperbaiki sumber daya manusia melalui kegiatan penyuluhan pertanian (Departemen Pertanian, 2008). Salah satu faktor yang berperan dalam peningkatan produktifitas pangan adalah melakukan kegiatan penyuluhan yang sistematis.

Kegiatan penyuluhan yang sistematis merupakan salah satu faktor penentu dalam meningkatkan produkivitas pangan. Salah satu tanaman pangan utama adalah padi. Penggunaan sarana produksi dan sistem budidaya padi modern mampu meningkatkan produktifitas padi menjadi 2-4 ton/ha (Subejo, 2010).

Pupuk organik cair adalah jenis pupuk berbentuk cair yang mudah larut pada tanah dan membawa unsur-unsur penting untuk kesuburan tanah. Pupuk organik cair dapat memberikan hara pada tanah yang sesuai dengan kebutuhan tanaman, karena bentuknya yang cair, jika terjadi kelebihan kapasitas pupuk pada tanah maka dengan sendirinya tanaman akan mudah mengatur pemupukan agar lebih merata, sehingga tidak akan terjadi penumpukan konsentrasi pupuk di satu tempat (Slamet, 2005). Menurut Amilia (2011), penggunaan pupuk organik cair dapat meningkatkan pertumbuhan, komponen hasil, dan hasil padi di sawah.

Sebagian besar petani padi di Gampong Blang Cut, Kecamatan Sukamakmur, Kabupaten Aceh Besar masih mengandalkan cara konvensional dalam bertani yaitu menggunakan pupuk kimia untuk membantu pertumbuhan dan meningkatkan produktivitas tanaman padi. Penggunaan pupuk organik cair di Gampong Blang Cut dimulai sejak tahun 2016 melalui distributor pupuk organik. Distributor tersebut memberikan informasi dan penjelasan mengenai pupuk organik cair sehingga beberapa petani bersedia menggunakan pupuk organik cair sebagai uji coba. Hasil panen yang didapat dari penggunaan pupuk organik cair ternyata jauh lebih besar dibandingkan dari penggunaan pupuk kimia saja.

Berdasarkan latar belakang diatas, maka dapat diidentifikasi perrmasalahan,yaitu :1. faktor-faktor apa saja yang mempengaruhi respon petani padi sawah terhadap penggunaan pupuk organik cair ?2. Bagaimana respon petani sawah terhadap penggunaan pupuk organik cair ?. Adapun tujuan dari penelitian ini adalah: 1. Mengetahui faktor yang mempengaruhi respon petani padi terhadap penggunaan pupuk organik cair. 2. Mengetahui Bagaimana respon petani padi terhadap penggunaan pupuk organik cair.

\section{METODE PENELITIAN}

Penelitian ini dilakukan di Gampong Blang Cut Kecamatan Suka Makmur Kabupaten Aceh Besar. Penentuan lokasi penelitian dilakukan dengan pertimbangan bahwa daerah tersebut merupakan salah satu daerah yang petaninya menggunakan pupuk organik cair. Objek penelitian adalah petani padi sawah yang menggunakan pupuk organik cair dalam proses budidaya padi sawah yang terdapat di lokasi tersebut. Ruang lingkup penelitian ini hanya terbatas pada masalah faktor apa saja yang mempengaruhi respon petani dan bagaimana respon petani padi sawah terhadap penggunaan pupuk organik cair di Gapong Blang Cut Kecamatan Suka Makmur Kabupaten Aceh Besar. 
Pengamatan secara observasi langsung ke lokasi penelitian dengan menggunakan metode survei ke petani yang menggunakan pupuk organik cair yang berada di daerah penelitian. Metode survei adalah metode yang dilakukan untuk mengumpulkan data-data atau fakta-fakta dilapangan berupa gejala yang terjadi di lapangan secara aktual tentang institusi sosial dan ekonomi dari satu kelompok (Nazir, 2003).Penelitian ini mengambil sampel secara proportional random sampling karena populasinya sedikit sehingga sampel diambil secara keseluruhan. Sampel yang diambil merupakan masyarakat petani yang ada di Gampong Blang Cut Kecamatan Suka Makmur Kabupaten Aceh Besar berjumlah 20 orang. Analisis Penelitian

Analisis data yang digunakan merupakan analisis deskriptif yang dianalisis dengan menggunakan likert scale (skala likert) dimana menurut Ridwan (2008) dalam buku rumus dan data dalam analisis statistika sebagai berikut :

Rumus Penentuan Interval :

$$
\begin{aligned}
& \mathrm{I}=\frac{J}{K} \\
& \mathrm{I}=\text { Interval } \\
& \mathrm{J}=\mathrm{Jarak} \text { kelas (\%skor maks }-\% \text { skor min) } \\
& \mathrm{K}=\text { Jumlah interval kelas }
\end{aligned}
$$

Dari rumus diatas dapat ditentukan penilaian kategori pengetahuan, sikap dan keterampilan petani terhadap penggunaan pupuk organik adalah sebagai berikut :

$$
\mathrm{I}=(100-0) / 3=33,33
$$

Skor Maksimum $=100$

Skor Minimum $=33,33$

Kategori $=3$

Kategori adalah :

Tinggi (3) : jika skor yang dicapai antara 77,79\% - 100\%

Sedang (2) : jika skor yang dicapai antara $55,56 \%-77,78 \%$

Rendah (1) : jika skor yang dicapai antara 33,33\% - 55,55\%

Untuk mengetahui tingkat respon petani terhadap penggunaan pupuk organik digunakan standar sebagai berikut : a. Apabila hasil analisis yang didapat tinggi, maka petani sudah menggunakan pupuk organik sesuai anjuran, b. Apabila hasil analisis yang didapat sedang, maka petani sudah menggunakan pupuk organik tetapi tidak sesuai anjuran, c. Apabila hasil analisis yang didapat rendah, maka petani tidak menggunakan pupuk organik.

\section{faktor internal}

\section{HASIL PENELITIAN DAN PEMBAHASAN}

Faktor internal merupakan faktor yang berasal dari dalam diri individu seseorang yang berpengaruh dalam menanggapi (merespon) rangsangan (stimulus) dari luar. Analisis faktor internal mempengaruhi respon dimaksudkan untuk melakukan kajian terhadap faktor diri yang mempengaruhi baik-kurangnya respon seseorang terhadap hal yang baru. Faktor internal yang diteliti dalam penelitian ini meliputi usia, pendidikan, dan pendapatan petani. Faktor internal yang mempengaruhi respon petani dalam menggunakan pupuk organik cair adalah sebagai berikut:

\section{Usia}


Usia merupakan lama hidup petani responden sampai pada saat penelitian dilakukan dinyatakan dalam tahun. Dapat dilihat pada tabel berikut ini :

Tabel 1. usia petani responden

\begin{tabular}{cccc}
\hline Usia & Skor & Responden & Persentase $(\%)$ \\
\hline Lebih dari 60 tahun & 1 & - & - \\
40 sampai 60 tahun & 2 & 7 & 35 \\
Dibawah 40 tahun & 3 & 13 & 65 \\
\hline Jumlah & & 20 & 100 \\
\hline
\end{tabular}

Sumber: Data primer, (2017)

Berdasarkan Tabel 1, maka dapat diketahui bahwa sebesar $65 \%$ petani responden yang terdapat di Gampong Blang cut dalam kategori muda yaitu dibawah 40 tahun. Usia terendah petani responden adalah 30 tahun dan usia tertinggi 57 tahun. Berdasarkan perhitungan usia rata-rata responden adalah 43 tahun. Usia muda mempunyai semangat kerja tinggi karena mempunyai beban tanggungan keluarga sehingga mudah untuk menanggapi hal-hal yang baru. Dari segi fisik, usia muda cenderung lebih kuat dibanding usia tua. Walaupun demikian, usia tua sudah lebih dahulu dan lebih lama terjun dalam kegiatan usahatani, mereka cenderung mempunyai pengalaman.

Dari hasil di lapangan didapatkan faktor usia tidak berpengaruh signifikan terhadap pengetahuan, sikap, dan tindakan petani responden. Akan tetapi respon petani lebih dipengaruhi oleh bukti yang telah dilihat di lingkungan mereka tinggal. Petani cenderung mengamati dan menilai hasil dari petani lain yang lebih dahulu menggunakan pupuk organik cair. Setelah mengetahui keunggulan pupuk organik cair dibanding pupuk lain, mereka baru setuju dan merencanakan dan pada akhirnya menggunakan pupuk tersebut. Baik petani muda maupun petani tua akan meniru hal-hal yang bermanfaat dari petani di lingkungannya.

\section{Pendidikan formal}

Pendidikan adalah tingkat pendidikan yang ditamatkan petani responden pada bangku sekolah atau lembaga pendidikan formal saat penelitian dilakukan. Analisis variabel pendidikan formal yang telah ditempuh petani dapat dilihat pada tabel 2 sebagai berikut:

Tabel 2. Pendidikan formal petani responden

\begin{tabular}{cccc}
\hline Pendidikan & Skor & Responden & Persentase $(\%)$ \\
\hline Diploma - Sarjana & 3 & 5 & 25 \\
Tamat SMP - SMA & 2 & 12 & 60 \\
Tamat SD/SR & 1 & 3 & 15 \\
\hline Jumlah & & 20 & 100 \\
\hline
\end{tabular}

Sumber: Data primer, (2017)

Berdasarkan Tabel 2, maka dapat diketahui bahwa pendidikan formal petani responden sebagian besar dalam kategori sedang yaitu sebanyak $12(60 \%)$ petani responden menyelesaikan pendidikanSMP/SMA, sebanyak 5 (25\%) petani responden menempuh pendidikan DIPLOMA/SARJANA dan sebanyak 3 (15\%) menyelesaikan SD/SR. Sebagian petani responden tidak takut mencoba pupuk organik cair sehingga seiring berjalannya waktu petani responden memperoleh manfaat dari pupuk organik cair.

Pendidikan formal tidak mempengaruhi pengetahuan, sikap, dan praktek petani terhadap pupuk organik cair organik cair. Informasi tentang pupuk organik cair diterima petani melalui pertemuan penyuluhan pada tahun sebelumnya dan informasi dari petani yang sudah menggunakan terlebih dahulu. Hal ini membuktikan bahwa perbedaan pendidikan tidak memberi pengaruh yang signitifan terhadap pengetahuan, sikap, dan tindakan petani 
mengenai pupuk organik cair.

\section{Pendidikan non formal petani}

Pendidikan non-formal merupakan tingkatan pendidikan yang pernah didapatkan oleh petani responden diluar pendidikan formal yaitu meliputi penyuluhan dalam pupuk organik cair dan masalah pertanian lainnya.

Tabel 3. pendidikan non formal petani responden

\begin{tabular}{cccc}
\hline $\begin{array}{c}\text { Pendidikan non } \\
\text { formal }\end{array}$ & Skor & Responden & Persentase (\%) \\
\hline Tinggi & 3 & - & - \\
Sedang & 2 & 8 & 40 \\
Rendah & 1 & 12 & 60 \\
\hline Jumlah & & 20 & 100 \\
\hline
\end{tabular}

Sumber : Data primer, (2017)

Berdasarkan Tabel 3, maka dapat diketahui bahwa pendidikan non-formal tidak memberikan pengaruh yang signifikan terhadap penggunaan pupuk organik cair, dimana pendidikan non formal petani responden Gampong Blang Cut sebagian besar berada dalam kategori rendah. Sebanyak 8 (40\%) petani responden dalam kategori sedang, sedangkan 12 $(60 \%)$ petani responden dalam kategori rendah. Berdasarkan hasil temuan dilapangan, tahun 2017 petani responden hanya mengikuti kegiatan penyuluhan sebanyak 3 kali dalam setahun. Dari 3 kali pertemuan hanya sekali pertemuan yang membahas tentang pupuk organik cair dan selebihnya membahas hal lain dari bidang pertanian, seperti pengaturan jarak tanam, pemilihan bibit/benih, dan pemberantasan hama penyakit. Hal ini menyebabkan petani responden kurang mendapat penyuluhan tentang penggunaan pupuk organik cair pada tahun ini. Pada akhirnya petani cenderung bertanya dan mengamati hasil-hasil yang diterima oleh petani yang menggunakan. Sehingga pengetahuan tentang pupuk organik cair dapat juga dimengerti walaupun terbatas.

Penyuluhan dan pelatihan mempengaruhi pengetahuan responden tentang adanya inovasi baru yang ada. Diharapkan dengan adanya perkembangan ilmu pengetahuan bidang pertanian aliran informasi kepada petani dapat dilakukan dengan tepat.

\section{Pendapatan}

Pendapatan merupakan total pendapatan yang diterima petani responden yang berasal dari usahatani dan non-usahatani dalam satu musim tanam (4 bulan) yang dinyatakan dalam rupiah. Analisis pendapatan usahatani dapat dilihat pada tabel sebagai berikut:

Tabel 4.Pendapatan Usahatani Padi Responden dalam 1 Musim tanam

\begin{tabular}{cccc}
\hline Pendapatan & Skor & Responden & Persentase (\%) \\
\hline Lebih dari 3.000 .00 & 1 & 6 & 30 \\
$2.500 .000-$ & 2 & 12 & 60 \\
3.000 .000 & & & 10 \\
Kurang dari & 3 & 2 & 100 \\
2.500.000 & & 20 &
\end{tabular}

Sumber : Data primer, (2017)

Berdasarkan Tabel 4, dapat diketahui bahwa pendapatan usahatani padi petani responden gampong blang cut sebagian besar dalam kategori sedang. Sebanyak 12 (60\%) petani responden memperoleh pendapatan dari dari Rp. 2.500 .000 - 3.000.000,-. Sebanyak $2(10 \%)$ petani responden memperoleh pendapatan kurang dari Rp. 2.500 .000 dan $6(30 \%)$ 
petani responden mempunyai pendapatan lebih dari Rp. 3.000.000,-. Pendapatan usahatani padi terendah petani responden adalah $\mathrm{Rp} 2.100,000$,- dan pendapatan tertinggi adalah $\mathrm{Rp}$ 3.200.000,-. Berdasarkan perhitungan, pendapatan rata-rata petani responden adalah Rp. 2.790 .000

Berdasarkan hasil di lapangan, diketahui bahwa luas lahan terkecil responden 0,125 ha dan lahan terbesar 0,25 ha. Rata-rata luas lahan adalah 0,187 ha. Para petani disini juga menggunakan pupuk anorganik. Akan tetapi penggunaan sedikit lebih berkurang dari penggunaan pupuk anorganik secara sistem konvensional. Disini petani menggunakan 3 jenis pupuk anorganik yaitu : Urea, TSP, dan NPK. Dimana masing - masing dari pupuk itu secara rata - rata digunakan sebamyak Urea $30 \mathrm{Kg}$, TSP 37,5 Kg, dan NPK $11.25 \mathrm{Kg}$, dengan produksi padi sebelum menggunakan pupuk organik cair adalah $585 \mathrm{~kg} / \mathrm{musim}$ tanam. Sedangkan, produksi padi setelah menggunakan pupuk organik cair dam juga dikombinasikan dengan pupuk anorganik adalah $780 \mathrm{~kg} / \mathrm{musim}$ tanam. Dari uraian di atas dapat diketahui selisih sebelum dan sesudah menggunakan pupuk organik sebesar $195 \mathrm{~kg}$ per musim tanam. Hal ini menunjukkan bahwa pendapatan tidak mempengaruhi respon petani padi dalam menggunakan pupuk organik cair. Pendapatan petani responden sebagian besar dalam kategori sedang. Sebanyak $12(60 \%)$ petani responden memperoleh pendapatan kurang dari Rp 2.500.000 - 3.000.000.

\section{Faktor eksternal}

Faktor eksternal merupakan faktor dari luar yang mempengaruhi seseorang memberikan tanggapan (respon). Dalam hal ini faktor dari luar berasal dari pupuk organik cair bila digunakan dalam usahatani. Faktor - faktor tersebut antara lain: manfaat yang diharapkan, waktu antara awal penggunaan dengan penerimaan manfaat dan besar enersi atau korbananyang dikeluarkan sehingga dapat menggunakan pupuk organik cair.

Faktor eksternal yang mempengaruhi respon petani dalam menggunakan pupuk organik cair di Gampong Blang Cut sebagai berikut:

\section{Manfaat yang diharapkan}

Manfaat yang diharapkan adalah keuntungan yang diperoleh petani responden menggunakan pupuk organik cair. Analisis manfaat yang diharapkan dapat dilihat pada tabel sebagai berikut :

Tabel 5. Manfaat yang diharapkan

\begin{tabular}{|c|c|c|c|c|}
\hline $\begin{array}{c}\text { Manfaat yang } \\
\text { diharapkan }\end{array}$ & Skor & $\begin{array}{c}\text { Responden } \\
\text { (orang })\end{array}$ & Persentase & Total skor \\
\hline Tinggi & 3 & 13 & $65 \%$ & 117 \\
\hline Sedang & 2 & 7 & $35 \%$ & 42 \\
\hline Rendah & 1 & - & - & - \\
\hline Jumlah & & 20 & $100 \%$ & \\
\hline
\end{tabular}

Sumber : Data primer, (2017)

Berdasarkan Tabel 5, maka dapat diketahui bahwa sebagian besar manfaat yang diharapkan dalam kategori tinggi. Sebanyak 13 (65\%) petani responden menganggap pupuk organik cair sangat membantu dalam memenuhi kebutuhan pupuk, membantu dalam meningkatkan produksi padi, dan membantu atau mempermudah dalam pengolahan lahan. Dan sebanyak 7 (35\%) petani mengangap pupuk organik cair tidak terlalu membantu dalam memenuhi kebutuhan pupuk, dalam meningkatkan produksi padi, dan tidak terlalu membantu atau mempermudah dalam pengolahan lahan. 
Hal ini menunjukkan bahwa manfaat yang diharapkan mempengaruhi petani untuk menggali lebih dalam pengetahuan dan informasi mengenai pupuk organik cair. Pengetahuan mengenai kandungan, tujuan diproduksi dan manfaat pupuk yang akan diterima mempengaruhi penggunaan pupuk. Dengan pengetahuan yang cukup, petani akan semakin percaya dan mau menggunakan pupuk organik. Dari hasil dilapangan didapati Manfaat yang diterima petani antara lain : kebutuhan pupuk petani terpenuhi, penggunaan pupuk organik cair juga mampu meningkatkan hasil rata-rata dari $585 \mathrm{~kg} /$ musim tanam menjadi 780 $\mathrm{Kg} /$ musim tanam. Lahan sawah yang dipupuk dengan pupuk organik cair juga lebih mudah proses pengolahannya untuk musim tanam selanjutnya. Hal ini terbukti bahwa waktu pembajakan tanah lebih efisien.

Walaupum demikian bukan berarti petani tidak menggunakan pupuk anorganik. Akan tetapi penggunaan sedikit lebih berkurang dari penggunaan pupuk anorganik secara sistem konvensional. Disini petani menggunakan 3 jenis pupuk anorganik yaitu : Urea, TSP, dan NPK. Dimana masing - masing dari pupuk itu secara rata - rata digunakan sebamyak Urea $30 \mathrm{Kg}$, TSP 37,5 Kg, dan NPK $11.25 \mathrm{Kg}$, dengan adanya kombinasi antara POC dan pupuk anorganik ini sangat membantu pemupukan dan hasil produksi yang lebih baik.

\section{Selang Waktu antara Awal Penggunaan dengan Memperoleh Manfaat}

Selang waktu antara awal penggunaan dengan memperoleh manfaat adalah jarak waktu dari awal penggunaan pupuk organik cair hingga memperoleh keuntungan. Waktu antara awal penggunaan dengan memperoleh manfaat dapat dilihat pada Tabel berikut ini : Tabel 6. Selang waktu antara awal penggunaan dengan memperoleh manfaat

\begin{tabular}{|c|c|c|c|c|}
\hline $\begin{array}{c}\text { Selang waktu antara awal } \\
\text { penggunaan dengan } \\
\text { memperoleh manfaat }\end{array}$ & Skor & $\begin{array}{c}\text { Responden } \\
\text { ( orang ) }\end{array}$ & persentase & $\begin{array}{c}\text { Total } \\
\text { skor }\end{array}$ \\
\hline Lama & 3 & 20 & $100 \%$ & 60 \\
\hline Sedang & 2 & - & & \\
\hline Cepat & 1 & - & - & \\
\hline Jumlah & & 20 & $100 \%$ & \\
\hline
\end{tabular}

Sumber : Data primer, (2017)

Berdasarkan Tabel 6, maka dapat diketahui bahwa petani responden menganggap waktu antara awal penggunaan dengan memperoleh manfaat sebagian besar dalam kategori lama. Sebanyak $20(100 \%)$ petani responden berpendapat bahwa sesuai dengan sifat pupuk organik, pupuk organik cair lebih lama memberikan manfaat dibanding dengan pupuk kimia. Hal ini menunjukkan bahwa waktu antara penyampaian tanggapan dengan memperoleh manfaat mempengaruhi respon petani padi dalam penggunaan pupuk organik cair.

Semakin lama waktu menerima manfaat maka respon petani terhadap pupuk organik cair semakin tinggi.Walaupun demikian penggunan pupuk anorganik juga masih digunakan. Dengan tujuan untuk memenuhi kebutuhan pupuk di lahan pertanian, para petani masih menggunakan pupuk anorganik untuk mengimbangi kebutuhan hara tanaman padi. Pertimbangan lain karena petani belum bisa meninggalkan kebiasaan menggunakan pupuk kimia.

\section{Besar Enersi/Korbanan yang Dikeluarkan}

Besar enersi/korbanan yang dikeluarkan adalah biaya membeli_pupuk organik cair yang digunakan petani responden untuk usahatani_padi. Besar biaya dalam variabel ini yang diteliti adalah harga yang_diterima petani, lokasi pembelian pupuk. 
Tabel 7. Besar enersi/korbanan yang dikeluarkan

\begin{tabular}{|c|c|c|c|c|}
\hline $\begin{array}{c}\text { Besar } \text { enersi/korbanan yang } \\
\text { dikeluarkan }\end{array}$ & Skor & $\begin{array}{c}\text { Responden } \\
\text { (orang })\end{array}$ & persentase & Total skor \\
\hline tinggi & 1 & & & \\
\hline Sedang & 2 & & & \\
\hline rendah & 3 & 20 & $100 \%$ & 60 \\
\hline jumlah & & 20 & $100 \%$ & \\
\hline
\end{tabular}

Sumber : Data primer, (2017)

Berdasarkan Tabel 7, maka dapat diketahui bahwa besar enersi/korbanan yang dikeluarkan responden sebagian besar dalam kategori rendah. Sebanyak 20 (100\%) petani responden membeli pupuk organik cair dari distributor pupuk. Adapun 20( 100\%) petani responden mengatakan harga yang dijual oleh distributor lebih murah dari harga kios enceran tertinggi . Dengan demikian responden cenderung membeli pupuk pada distributor pupuk karena adanya jaminan persediaan pupuk selalu ada. Dengan pasokan pupuk yang cukup di gampong blang cut menjadikan syarat pembelian pupuk organik semakin mudah. Petani hanya membawa biaya, pembelian pupuk sudah bisa dilayani.

Dari hasil temuan dilapangan besar enersi/korbanan yang dikeluarkan tidak berpengaruh dengan pengetahuan, sikap, dan tindakan petani terhadap pupuk organik cair. Dari temuan dilapangan renponden tidak mengalami kesulitan dalam memperleh pupuk. Harga yang ditawarkan mulai awal dikeluarkan hingga sekarang penggunaan cenderung lebih rendah.

\section{Respon Petani Padi dalam Menggunakan Pupuk organik cair}

Respon merupakan tanggapan seseorang terhadap sesuatu karena adanya stimulus tertentu. Respon diwujudkan dalam 3 macam, yaitu respon kognitif (tingkat pemahaman), respon afektif (sikap atau ketertarikan), serta respon perilaku atau konatif (tindakan dan pernyataan mangenai perilaku). Respon petani dalam menggunakan pupuk organik cair di gampong blang cut adalah sebagai berikut :

\section{Respon Kognitif}

Respon kognitif merupakan tingkat pemahaman petani responden terhadap pupuk organik cair. Berikut adalah tabel untuk respon kognitif penggunaan pupuk organic cair.

Tabel 8. Respon kognitif penggunaan pupuk organic cair

\begin{tabular}{|c|c|c|c|c|}
\hline Respon kognitif & Skor & $\begin{array}{c}\text { Responden } \\
\text { (orang })\end{array}$ & persentase & Total skor \\
\hline Baik & 3 & 15 & $75 \%$ & 180 \\
\hline Sedang & 2 & 5 & $25 \%$ & 40 \\
\hline Kurang & 1 & - & - & - \\
\hline Jumlah & & 20 & $100 \%$ & \\
\hline
\end{tabular}

Sumber : Data primer, (2017)

Berdasarkan tabel 8, maka dapat diketahui bahwa respon kognitif petani responden terhadap pupuk organik cair sebagian besar dalam kategori sedang. Sebanyak 15 (75\%) petani responden mengetahui bahan baku pupuk, tujuan dikeluarkannya pupuk, manfaat dari pupuk, dosis penggunaan pupuk, waktu yang tepat penggunaan pupuk, dan keunggulan pupuk organik cair. Pengetahuan responden diperoleh dari penyuluhan periode tahun kemarin.

Di samping penyuluhan, petani responden dapat belajar dari pengalaman petani yang telah menggunakan pupuk dalam usahatani. Hasil di lapangan dapat diketahui bahwa selama 
penyuluhan dilakukan tidak semua petani memahami pupuk organik cair. Sebanyak 5 (25\%) petani responden belum mengetahui bahan baku pupuk dan belum mengetahui tujuan dikeluarkannya pupuk organik cair.

\section{Respon Afektif}

Respon afektif merupakan sikap petani responden terhadap pupuk organik cair yang selama ini diperkenalkan oleh petugas.Respon afektif dapat dilihat pada tabel sebagai berikut:

Tabel 9. Respon afektif penggunaan pupuk organic cair

\begin{tabular}{|c|c|c|c|c|}
\hline Respon afektif & Skor & $\begin{array}{c}\text { Responden } \\
\text { ( orang ) }\end{array}$ & persentase & Total skor \\
\hline baik & 3 & 14 & $70 \%$ & 126 \\
\hline Sedang & 2 & 6 & $30 \%$ & 36 \\
\hline kurang & 1 & - & - & - \\
\hline jumlah & & 20 & $100 \%$ & \\
\hline
\end{tabular}

Sumber : Data primer, (2017)

Berdasarkan Tabel 9, maka dapat diketahui bahwa respon afektif atau sikap petani responden terhadap pupuk organik cair sebagian besar dalam kategori sedang. Sebanyak 14 (70 \%) petani responden setuju bahwa pupuk organik cair meningkatkan produksi pertanian, menghemat pupuk kimia komersial, karena kebutuhan pupuk digantikan pupuk organik cair dan dibantu dengan pupuk kandang. Dalam hal ini petani membedakan antara hemat biaya pembelian pupuk kimia komersial yang harganya lebih tinggi dari pupuk organik cair. Selain hal diatas, responden setuju pupuk organik dapat menjaga dan mengembalikan kesuburan tanah, dan meningkatkan daya beli pasar dengan hasil pertanian organik.

Hasil di lapangan menunjukkan bahwa pengetahuan petani mengenai pupuk organik cair berpengaruh terhadap sikap yang diberikan. Pernyataan setuju dalam hal meningkatkan daya beli pasar organik dapat diketahui ketika sebagian petani menerapkan pertanian organik ada beberapa tetangga yang memesan hasil panen. Dari wawancara yang dilakukan, beras organik lebih enak, pulen dan tahan lama dari pada beras non-organik apabila dimasak. Sebanyak $6(30 \%)$ petani responden tidak terlalu setuju apabila pupuk organik menghemat pupuk akan tetapi mereka cenderung berpendapat bahwa kebutuhan menggunakan pupuk organik lebih banyak dari pada pupuk kimia yang lain.

\section{Respon Konatif}

Respon konatif merupakan volume penggunaan pupuk organik cair yang diaplikasikan petani responden dalam usahatani. Analisis respon konatif dapat dilihat pada tabel :

Tabel 10. Respon konatif penggunaan pupuk organik cair

\begin{tabular}{|c|c|c|c|c|}
\hline Respon konatif & Skor & $\begin{array}{c}\text { Responden } \\
\text { (orang })\end{array}$ & persentase & Total skor \\
\hline baik & 3 & 6 & $30 \%$ & 18 \\
\hline Sedang & 2 & 10 & $50 \%$ & 20 \\
\hline kurang & 1 & 4 & $20 \%$ & 4 \\
\hline jumlah & & 20 & $100 \%$ & \\
\hline
\end{tabular}

Sumber : Data primer, (2017)

Berdasarkan tabel 10, dapat diketahui bahwa respon konatif petani responden dalam menggunakan pupuk organik cair sebagaian besar berada dalam kategori rendah. Sebanyak 
6 petani responden ( $30 \%$ ) menggunakan pupuk organik cair lebih dari duapertiga dosis yang dianjurkan. Sebanyak $10(50 \%)$ petani responden menggunakan sepertiga hingga dua pertiga dari dosis yang dianjurkan. Dan sebanyak 4 (20\%) petani responden menggunakan pupuk kurang dari sepertiga dosis yang dianjurkan.

Penggunaan pupuk organik cair oleh petani responden dalam usahatani ditentukan oleh pengetahuan dan sikap yang diberikan. Sebagian besar petani responden menerima pengetahuan yang sama. Pengetahuan selanjutnya menentukan sikap yang diberikan. Sikap terdiri dari dua pilihan, yaitu menerima atau menolak pupuk tersebut. Apabila menerima, maka dapat diwujudkan dengan menggunakan pupuk organik cair dalam usahatani. Begitu sebaliknya, apabila menolak maka petani tidak menggunakan pupuk organik cair.

\section{SIMPULAN DAN SARAN}

\section{Kesimpulan}

Berdasarkan dari hasil penelitian yang di lakukan di gampong blang cut kecamatan sukamakmur kabupaten aceh besar dapat di simpulkan sebagai berikut :

1. Diketahui bahwa faktor - faktor internal (usia, pendidikan, pendapatan) tidak memberi pengaruh yang signifikan terhadap respon petani responden, karena sebagian besar respon petani dalam kategori sedang yaitu masing- masing skor $65 \%$ untuk usia, $60 \%$ untuk pendidikan, dan $60 \%$ untuk pendapatan.

2. Diketahui bahwa faktor - faktor eksternal (manfaat yang diharapkan, waktu antara awal penggunaan dengan memperoleh manfaat, enersi/korbanan yang dikeluarkan) memberi pengaruh yang signifikan, karena berada kategori tinggi yaitu masingmasing skor (65\%) untuk manfaat yang diharapkan, (100\%) untuk selang waktu antara awal penggunaan dengan memperoleh manfaat, dan $100 \%$ untuk besar enersi/korbanan yang dikeluarkan.

3. Respon kognitif petani responden sebagian besar dalam kategori baik. Sebanyak $75 \%$ petani responden memahami pupuk organik cair.

4. Diketahui bahwa respon afektif atau sikap petani responden terhadap pupuk organik cair sebagian besar dalam kategori baik. Sebanyak 14 (70 \%) petani responden setuju bahwa pupuk organik cair meningkatkan produksi pertanian, menghemat pupuk kimia komersial.

5. Diketahui bahwa respon konatif petani responden dalam menggunakan pupuk organik cair sebagaian besar berada dalam kategori sedang. Sebanyak 10 (50\%) petani responden menggunakan sepertiga hingga dua pertiga dari dosis yang dianjurkan.

\section{SARAN}

Berdasarkan dari kesimpulan-kesimpulan yang telah di uraikan di atas maka penulis mengambil saran sebagai berikut :

1. Perlu adanya peningkatan kegiatan penyuluhan mengenai pupuk organik cair melalui pertemuan rutin dan Demontrasi Plot area. Sehingga perbaikan kondisi lahan dan peningkatan produksi budidaya tanaman padi dengan penggunaan pupuk organik cair dapat diketahui secara nyata oleh petani.

2. Diharapkan setiap petani menginvestasikan sebagian pendapatan dari hasil panen 
untuk memenuhi kebutuhan pupuk organik cair pada musim berikutnya. Dengan persediaan pupuk yang cukup, kebutuhan pemupukan tanaman padi akan terpenuhi.

3. Diharapkan kepada petani yang telah merasakan manfaat dari penggunaan pupuk organik cair, untuk dapat menghimbau dan mendorong petani lain yang belum berhasil dan belum menggunakan agar dapat menggunakan pupuk organik cair.

\section{DAFTAR PUSTAKA}

Amilia, Y. 2011. Penggunaan pupuk organik cair untuk mengurangi dosis penggunaan pupuk anorganik pada padi sawah (Oryza sativa L.). Skripsi. Institut Pertanian Bogor, Bogor.

Departemen pertanian. 2008. Kebijakan Teknis Program Pengembangan Usaha Agribisnis Perdesaan. Jakarta : departemen pertanian

Moch, N. 2003. Metode Penelitian. Salemba Empat, Jakarta.

Murbandono, H. L. 2000. Membuat Kompos. Penebar Swadaya, Jakarta.

Rahman, A. 2004. Pertumbuhan dan Produksi Tanaman Sawi Dengan Pemberian Bokashi, Jurnal Agrisisten 4(2): 75-80

Reksoprayitno, S. 2000. Ekonomi Makro. Penerbit BPFE, Yogyakarta.

Ridwan. 2007. Skala Pengukuran Variabel-variabel Penelitian. Bandung : Alfabeta

Slamet, R., Arbiati, dan Daryanto. 2005. Pengolahan Limbah Organik (Fenol) dan Logam Berat $\left(\mathrm{Cr}_{6}{ }^{+}\right.$atau $\left.\mathrm{Pt}_{4}{ }^{+}\right)$Secara Simultan dengan Fotokalis $\mathrm{TiO}_{2}, \mathrm{ZnO}-\mathrm{TiO}_{2}$ dan $\mathrm{CdS}$ $\mathrm{TiO}_{2}$. Jurnal Makara Teknologi. 9(2): 1-3.

Subejo, 2010. Pengertian penyuluhan dan lingkup penyuluhan, http://www.subejo.com.

Diakses tanggal: 10 April 2016.

Djamhur Hamid. 2016. Dampak Pengembangan Pariwisata Terhadap Kehidupan

Sumarwan, U. 2003. Perilaku Konsumen. Penerbit Ghalia Indonesia, Jakarta.

Sutanto, R. 2002. Penerapan Pertanian Organik. Permasyarakatan dan Pengembangannya. Kanisius, Yogyakarta.

Walgito, B. 2002. Pengantar Psikologi Umum. Edisi 3. Yogyakarta.

Yulipriyanto,H. 2010. Biologi Tanah dan Strategi Pengolahannya. Yogyakarta. 